\title{
Corncob residue as heterogeneous acid catalyst for green synthesis of biodiesel: A short review
}

\author{
Primata Mardina*, Hesti Wijayanti, Abubakar Tuhuloula, Erita Hijriyati, Sarifah \\ Chemical Engineering Department, Lambung Mangkurat University, Banjarbaru 70714, Indonesia
}

Article history:

Received: 5 July 2021 / Received in revised form: 3 October 2021 / Accepted: 28 October 2021

\begin{abstract}
The utilization of an appropriate catalyst in biodiesel production depends on the free fatty acid content of vegetable oil as a feedstock. Recently, heterogeneous acid catalysts are widely chosen for biodiesel production. However, these catalysts are non-renewable, highly expensive and low stability. Due to the aforementioned drawbacks of commercial heterogeneous acid catalyst, a number of efforts have been made to develop renewable green solid acid catalysts derived from biomass. Published literature revealed that the application of the biomass derived solid acid catalysts can achieve up to $98 \%$ yield of biodiesel. This article focused on corncob as raw material in solid acid catalyst preparation for biodiesel production. The efficient preparation method and performance comparation are discussed here. The corncob derived heterogeneous acid catalysts provides an environmentally friendly and green synthesis for biodiesel production.
\end{abstract}

Keywords: Biodiesel; heterogeneous acid catalysts; green synthesis; biomass; corncob

\section{Introduction}

The depletion and drawbacks of fossil fuel have shifted the world attention to renewable energy sources [1-3]. It leads biofuel such as biodiesel and bioethanol have become more attractive as an alternative green fuel [4-7]. Biodiesel is a substitute for petroleum-based diesel fuel and it offers several advantages including clean emission, non-toxicity, and biodegradability [8-9]. Moreover, biodiesel possesses higher flashpoint, higher cetane number [10-11], and zerocomposition of sulfur provides better lubricity compared to diesel fuel [12].

Biodiesel, generally known as fatty acid methyl ester (FAME), is derived by the transesterification or esterification of vegetable oil and fat with short chain alcohol in the presence of a catalyst (figure 1) [13-15]. Commonly, transesterification/esterification is carried out by using homogeneous catalysts such as $\mathrm{NaOH}, \mathrm{KOH}$ and $\mathrm{H}_{2} \mathrm{SO}_{4}[16-$ 17], each of which has advantages and disadvantages. A homogeneous base catalyst offers high catalytic activities, a faster reaction rate, and a lower temperature reaction [18-19]. However, the reaction using a homogeneous base catalyst is very sensitive to the existence of free fatty acid (FFA) and water in the reaction system [20-21]. Furthermore, that kind of reaction induces soap formation and deters the purification process [20-22-23]. Meanwhile, a homogeneous acid catalyst is capable of processing the reaction that uses feedstock

* Corresponding author.

Email: pmardina@ulm.ac.id

https://doi.org/10.21924/cst.6.2.2021.460 containing high FFA without soap formation. Here, the very slow reaction rate and high corrosivity of acidic condition become the major drawbacks of the homogeneous acid catalyst utilization [24-25]. The consideration of negative effect homogeneous catalyst on transesterification/esterification generates a huge interest in the heterogeneous catalyst. It provides many advantages such as simple product separation and purification, non-corrosivity and recyclability [20-26].

The number of heterogeneous basic and acid catalysts has been studied, developed and successfully utilized in both laboratory and industry. Calcium oxide, calcium methoxide and hydrotalcite are commonly used as the solid basic catalysts in transesterification [13]. They give a promising catalytic activity in transesterification reaction with the high yield of biodiesel. Unfortunately, the heterogeneous basic catalyst is only suitable for highly refined vegetable oils $(\mathrm{FFA}<1 \%)$. The stability of heterogeneous basic catalyst could be low and reduced due to water and moisture during storage and handling [4]. The heterogeneous acid catalyst is more preferred to be used in biodiesel production using low quality vegetable oil (FFA $>1 \%$ ). It could be esterified FFA into biodiesel efficiently [2-27-28]. Mansir et al. [21] stated that the hydrophobic surface of the solid acid catalyst prevented the by-product such as water and glycerol to deactivate the active sites of the catalyst.

Zeolite, ion exchange resin, silica-alumina, sulfonated polystyrene and hetero-polyacids are the examples of heterogeneous acid catalyst that are generally used in biodiesel production [29]. 
(a)<smiles></smiles>

(b)

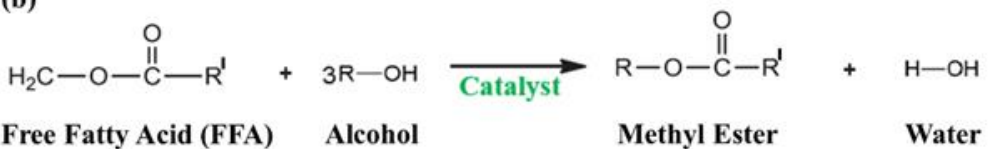

Fig. 1. (a) Transesterification reaction, and (b) esterification reaction for biodiesel production

The "green technology" principle drives the utilization of biomass as raw material for many purposes [7-30-34] including for the development of heterogeneous acid catalyst. The heterogenous acid catalysts that are prepared from biomass offer biodegradable and environmentally friendly catalyst, and it is considered as low-cost material [35]. Comparing the conventional solid acid catalyst such as Amberlyst-15, biomass provides higher surface area than conventional solid acid catalyst such as Amberlyst-15 [36]. The agricultural crop residues one example of biomass that recently gains an attention as the low-cost raw material for heterogenous acid catalyst preparation including sugarcane bagasse, oil palm trunk, peanut hull, sugar beet pulp, coconut shell, or corncob [35-37-39]. Based upon its chemical composition and abundant availability as agricultural residue, corncob is highly potential to be a solid acid catalyst for chemical reaction including the esterification of high-FFA vegetable oils to produce biodiesel. This study reviews the development of heterogeneous acid catalysts derived from corncob for biodiesel production. The preparation method of this catalyst here became the highlight of this study. The performance of corncob derived solid acid catalyst on biodiesel production was also compared to provide a better insight for their future development in the field of high active solid acid catalyst.

\section{Current Problem of Homogeneous Catalyst for Biodiesel Production.}

The most common method to produce biodiesel is by performing the transesterification reaction between vegetable oil and short chain alcohol in the presence of homogeneous base catalyst. This reaction gives a faster reaction rate and higher yield of biodiesel. Unfortunately, the alkalinecatalyzed transesterification is only suitable for high refined vegetable oil as the main raw material for biodiesel. Consequently, the low quality of raw material such as waste cooking/frying oil and non-edible vegetable oil lead to soap formation due to the high free fatty acid (FFA) and water content of those materials. The water will hydrolyze triglyceride and generate more FFA during reaction. Hence, the saponification reaction will occur along with the transesterification to form stable emulsion or soap. It will then consume large amount energy during purification. The one method to solve the problem of low-quality raw material is by using acid-catalyzed esterification and it is typically performed before the transesterification. The utilization of homogeneous acid catalyst is able to reduce and convert FFA into alkyl ester (biodiesel) efficiently in esterification reaction. However, the homogeneous acid catalyst leads to reactor corrosion. Another challenge of homogeneous acid catalyst utilization is the huge wastewater production during the purification process [40]. Heterogeneous catalyst is a good alternative to replace the homogeneous one. The heterogeneous catalyst provides a number of superior properties such as simple separation, being non-corrosive to reaction system and being environmentally friendly.

Many types of heterogeneous catalyst have been studied. It has been found that the catalyst is able to manage and reduce the FFA content of low-quality feedstock for biodiesel production process. Amberlyst, protonated-nafion, and sulfated zirconia are the heterogeneous acid catalysts applied in biodiesel synthesis. However, those catalysts have low acid density, the small pore size, faster deactivation, and low stability.

As the implementation of green technology, it is necessary to find the biodegradable, non-toxic, environmentally friendly, and low-cost material to synthesize the heterogeneous acid catalyst. Therefore, the lignocellulosic material exhibits a high potential as raw material of heterogeneous acid catalyst. Lignocellulose is plant dry matter, which is called biomass that is reliable to be converted into porous carbon material for solid catalyst preparation. Due to the requirement of low production cost, biomass waste is getting more popular as a solid catalyst raw material. It is found abundantly as the result of human agricultural activities [41-42]. The utilization of biomass waste also provides a solution for the disposal problem of biomass waste [43-44]. The transformation of biomass waste into heterogeneous catalyst can enhance their economic value [35]. Biomass waste derived heterogeneous catalyst may differ in surface porosity and structural properties due to the different chemical composition and physical properties of biomass waste [14]. 

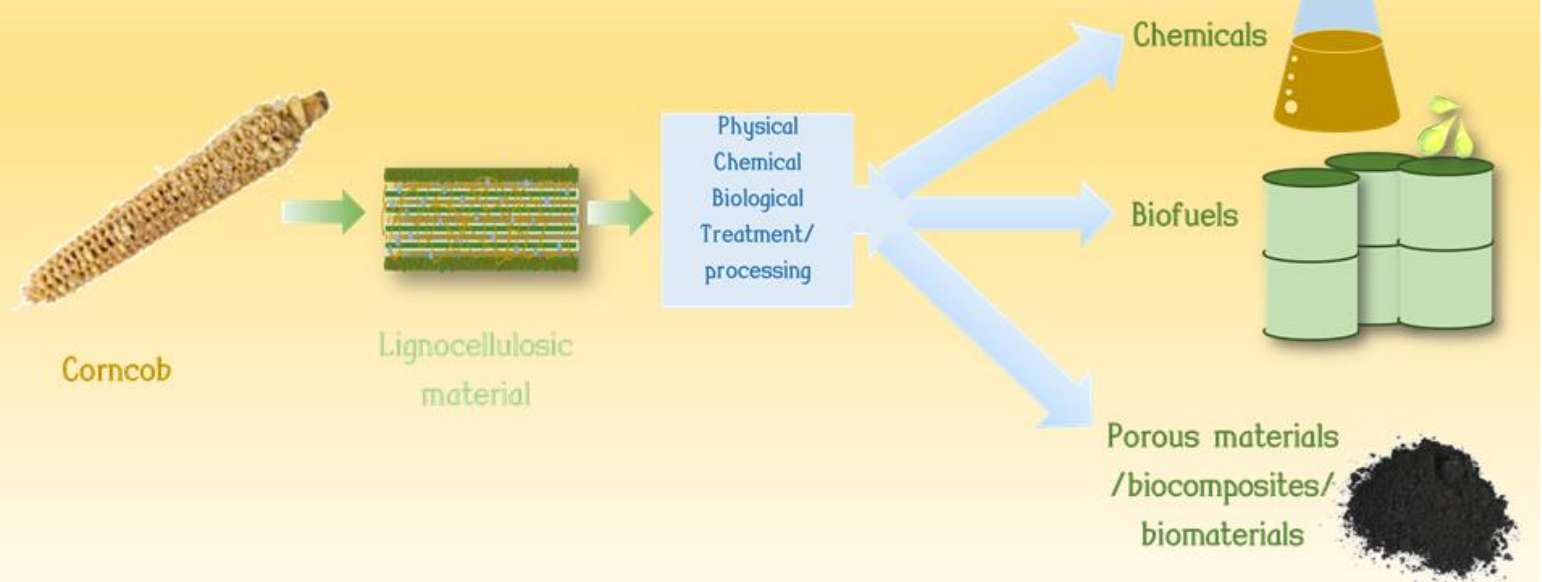

Fig. 2. Utilization of corncob residue for value-added materials

\section{Corncob Residue as a Heterogeneous Acid Catalyst for Biodiesel Production.}

Corn (Zea mays L.) is one of the largest agricultural crops in Indonesia besides rice. As reported by Ministry of Agriculture, annual corn production in Indonesia is 30 million tons per year [45]. It has been estimated that around $21 \%$ of the corn production will produce corncob as crop residue [46]. The large-scale of corncob residue as a byproduct of corn production presents new challenges and environmental issues to consider. Corncob residue is generally subjected to dump or incinerate causing air pollution. On small scale, corncob residue is used as a fuel in direct combustion for cooking, heating, and other purposes. It is necessary to find a solution to convert the corncob residue into high value-added materials by a simple green technology [47]. As an agricultural waste, corncob residue is mainly composed of lignin, cellulose, and hemicellulose. It has been found that corncob residue contains $42-45 \%$ of cellulose, $35-39 \%$ of hemicellulose and $14-15 \%$ of lignin [48]. Corncob residue is also composed of three tissue fractions: chaff, woody ring and pith [49]. Due to its chemical composition and structure, the corncob residue has an important application in biofuels, food, and chemical industries (figure 2) [50]. The requirement of low cost and green catalyst development which is derived from lignocellulosic material is a driving force to utilize corncob as a heterogeneous acid catalyst in chemical reactions [51-52]. The lignocellulosic content of corncob can be thermally treated and chemically activated into acidic carbon-based catalysts [39-51-53]. In addition, corncob has a fixed carbon content of $15.9 \% \mathrm{w} / \mathrm{w}$ [54], The value is comparable to other agricultural residues $(11.71-35.2 \% \mathrm{w} / \mathrm{w})$ that are used as the raw material for the synthesis of solid acid catalysts [55-58]. The previous researches mentioned exactly the same reason why the corncob has been selected as raw material for heterogeneous acid catalyst [50-53-59-60]. The corncobderived heterogeneous acid catalyst is expected to be used efficiently to catalyze the esterification reaction of low-quality feedstock in biodiesel production and could solve the current problem of catalyst utilization in biodiesel production. The high catalytic activity, simple separation, and the reusability are the main goal in corncob-derived heterogeneous acid catalyst synthesis process. To reach the goal, there are several techniques applied to synthesize and modify the corncobderived heterogeneous acid catalyst. The most common pathway employed to synthesize acid-activated solid catalysts from lignocellulosic materials is through carbonization, which is followed by chemical activation [61-64]. The lignocellulosic materials are carbonized to remove any volatile matters by thermal decomposition and obtain porous carbon. Nata et al. [65] carbonized a corn cob at $400^{\circ} \mathrm{C}$ for $1 \mathrm{~h}$ to generate biocarbon before chemical activation, and they found that the concentration of carbon increased up to $79.45 \%$. A similar method was also performed by Rocha et al. [51], who prepared a corncob-derived solid acid catalyst by carbonization at $500^{\circ} \mathrm{C}$ for $1 \mathrm{~h}$. To produce high-quality carbon, a hydrothermal carbonization method is offered. The carbon material is formed at low temperatures under highpressure conditions [66]. This method can generate a higher amount of porous hydrochar as a carbon product [67]. Ma et al. [39] performed hydrothermal carbonization at $180^{\circ} \mathrm{C}$ by using corncob as the feedstock. The same method was also used by Ibrahim et al. [53] for solid acid catalyst preparation from corncob. The hydrothermal carbonization was performed at $200^{\circ} \mathrm{C}$ for $10 \mathrm{~h}$. Those studies successfully exhibited hydrothermal carbonization as a suitable process to produce porous carbon materials.

To obtain a corncob-derived heterogeneous acid catalyst with high porosity and activity, chemical activation such as the sulfonation method was employed [35-68-69]. The simple way of sulfonation is by using thermal treatment of biochar with concentrated $\mathrm{H}_{2} \mathrm{SO}_{4}$ [24]. Fuming sulfuric acid [70], p-toluenesulfonic acid (PTSA) [44], 4benzenediazonium sulfonate [36], and hydroxyl ethyl sulfonic acid [65] also have been utilized as sulfonating agents. This sulfonation was performed by heating the mixture of biochar and sulfonating agent to synthesize the catalyst. There are two common ways of sulfonation on corn cob as acid catalyst preparation, reflux system, and thermal treatment using an autoclave Teflon reactor. These two methods have a different effect on BET surface area and pore properties of catalyst [53-71]. Ibrahim et al [53] found that the surface area of solid catalysts before and after sulfonation by using a reflux system 
was almost identical, i.e. $8.76 \mathrm{~m}^{2} \cdot \mathrm{g}^{-1}$ and $8.40 \mathrm{~m}^{2} \cdot \mathrm{g}^{-1}$, respectively. The pore properties slightly deteriorated and $\mathrm{SO}_{3} \mathrm{H}$ groups were dispersed and incorporated within the pores. Meanwhile, the sulfonation using thermal treatment provides high porosity that can enlarge the surface of the active area. Therefore, thermal treatment is more preferred to insert $-\mathrm{SO}_{3} \mathrm{H}$ groups into the surface of carbon precursor. Figure 3 describes the employed pathway to synthesize solid acid catalyst from corncob using thermal treatment.

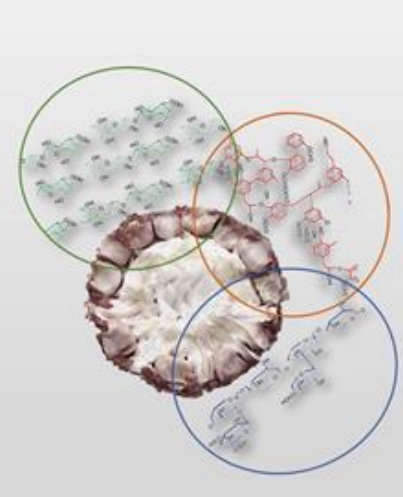

Corncob residue

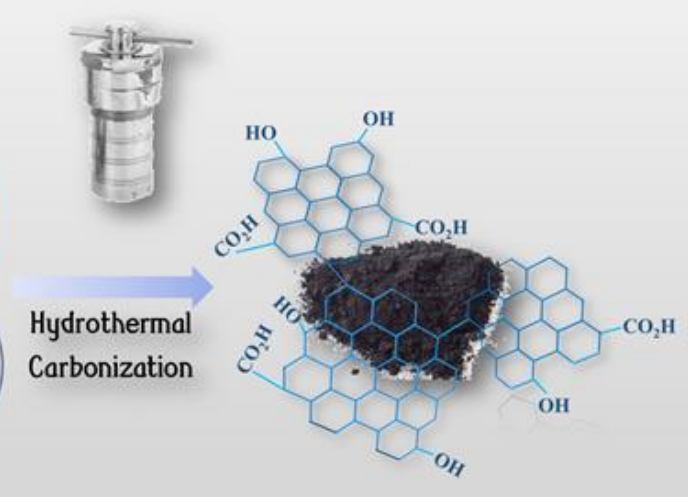

Carbon ring

structured material

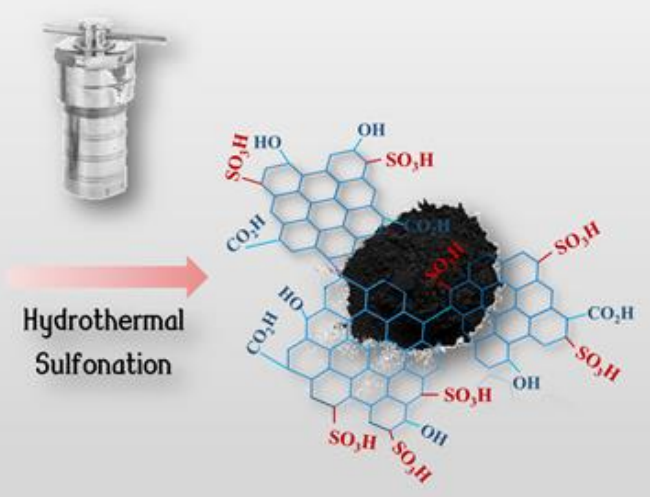

Sulfonated carbon acid catalyst

Fig. 3. Synthesis pathway of solid acid catalyst from corncob

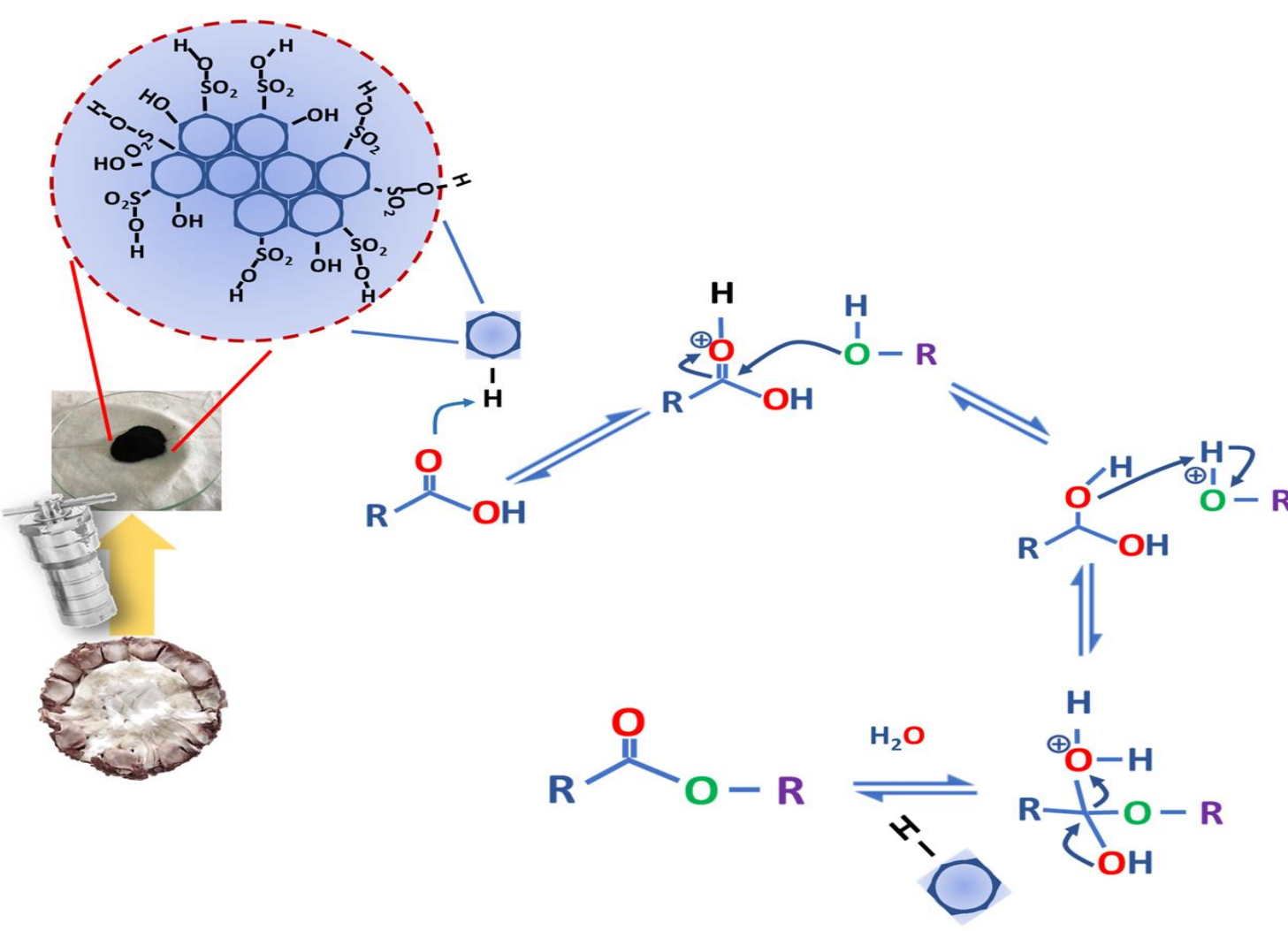

Fig. 4. Proposed mechanism pathways for esterification reaction using corncob derived sulfonated solid catalyst 
Table 1. A literature report on biodiesel production over corncob-derived solid acid catalysts

\begin{tabular}{|c|c|c|c|c|c|}
\hline $\begin{array}{c}\text { Catalyst preparation } \\
\text { method }\end{array}$ & $\begin{array}{c}\text { Esterification } \\
\text { feedstock }\end{array}$ & $\begin{array}{c}\text { Catalyst loading } \\
\text { (wt } \%)\end{array}$ & Temperature $\left({ }^{\circ} \mathrm{C}\right)$ & Yield/Conversion $(\%)$ & Refs. \\
\hline $\begin{array}{l}\text { Pyrolysis } \\
\text { carbonization and } \\
\text { sulfonation }\end{array}$ & $\begin{array}{l}\text { Highly acidic } \\
\text { waste oil }\end{array}$ & 3 & & 98 & [50] \\
\hline $\begin{array}{l}\text { Hydrothermal } \\
\text { carbonization and } \\
\text { hydrothermal } \\
\text { sulfonation }\end{array}$ & Oleic acid & 10 & 80 & 89.2 & [39] \\
\hline $\begin{array}{l}\text { Impregnation, } \\
\text { pyrolysis } \\
\text { carbonization and } \\
\text { sulfonation }\end{array}$ & Oleic acid & 10 & 65 & 90 & [59] \\
\hline $\begin{array}{l}\text { Impregnation, } \\
\text { pyrolysis } \\
\text { carbonization and } \\
\text { sulfonation }\end{array}$ & $\begin{array}{c}\text { Refined } \\
\text { soybean oil }\end{array}$ & 20 & 75 & 88.7 & {$[51]$} \\
\hline $\begin{array}{l}\text { Impregnation, } \\
\text { pyrolysis } \\
\text { carbonization and } \\
\text { sulfonation }\end{array}$ & $\begin{array}{l}\text { Palm fatty } \\
\text { acid distillate }\end{array}$ & 5 & 100 & 93.49 & {$[60]$} \\
\hline $\begin{array}{l}\text { Hydrothermal } \\
\text { carbonization and } \\
\text { reflux sulfonation }\end{array}$ & $\begin{array}{l}\text { Palm fatty } \\
\text { acid distillate }\end{array}$ & 3 & 70 & 92 & {$[53]$} \\
\hline
\end{tabular}

After sulfonation process, the surface area of corncobderived heterogeneous acid catalyst tended to decrease. It was due to the insertion of $-\mathrm{SO}_{3} \mathrm{H}$ groups on the surface. Hussain and Kumar [59] reported the change of surface area before and after sulfonation of corncob-derived heterogeneous catalyst in which the surface area decreased after sulfonation from $1268 \mathrm{~m}^{2} \cdot \mathrm{g}^{-1}$ to $641 \mathrm{~m}^{2} \cdot \mathrm{g}^{-1}$. They claimed that the decrease on surface area after sulfonation indicated that the $\mathrm{SO}_{3} \mathrm{H}$ groups successfully grafted onto surface, which acted as the active sites. The synthesized catalyst was applied in the esterification of Karanja oil in the presence of methanol. Th conversion of FFA reached $90 \%$. Rocha et al. [51] also reported the same tendency of decrease on the surface area of corncob-derived catalyst after sulfonation, from $739.4 \mathrm{~m}^{2} \cdot \mathrm{g}^{-1}$ to $730.8 \mathrm{~m}^{2} \cdot \mathrm{g}^{-1}$. They used the synthesized catalyst in the transesterification of soybean oil with ethanol, resulting in biodiesel yield of $88.7 \%$. On the other hand, the sulfonation process also generate larger pore size. Tang et al. [60] found that sulfonated-carbonized-corncob had larger average pore size $(3.79 \mathrm{~nm})$ compared to carbonized-corncob $(2.68 \mathrm{~nm})$. The catalyst was utilized in the esterification of palm fatty acid distillate with methanol and reached $93.49 \%$ of FFA conversion. Larger pore size provides the accessibility of reactants with large molecular size going to the active sites. The proper size of pore could reduce the mass transfer resistance of the flow of reactants to reach the active sites. Ngaosuwan et al. [72] mentioned that the FFA and triglyceride molecules could pass through a cylindrical pore with $2 \mathrm{~nm}$ diameter.

The heterogeneous acid catalyst can be classified into Brønsted-type (sulfonic acid-containing material) and Lewistype (mixed sulfated oxides-containing material). Both types of acid catalyst can be used in the esterification of FFA in the presence of short-chain alcohol to produce biodiesel. However, the mechanism is slightly different. The Brønstedtype catalyzes the esterification of FFA by the protonation of the acid group to give an oxonium ion, which is readily attacked by an alcohol through an exchange reaction to produce alkyl ester after losing proton. The Lewis-type catalyzes the esterification of FFA by direct coordination of the FFA to the acid metal site. Nata et al. [65] and Ibrahim et al. [53] confirmed the Brønsted acid-type on the corncobderived heterogeneous sulfonated catalyst by titration method and TPD- $\mathrm{NH}_{3}$ analysis. The sulfonated-carbonized corncob exhibited Brønsted acid sites at $\mathrm{T}_{\min } 120^{\circ} \mathrm{C}$ and $\mathrm{T}_{\max }=550^{\circ} \mathrm{C}$ with total acid density of $2.64 \mathrm{mmol} . \mathrm{g}^{-1}$ and $13.00 \mathrm{mmol} . \mathrm{g}^{-1}$, respectively. Furthermore, a high total acid density of corncob solid acid catalyst results in high FFA conversion and biodiesel yield. It is due to $-\mathrm{SO}_{3} \mathrm{H}$ that induces the hydrophilicity of the carbon surface from corncob, allowing alcohol molecules to enter the carbon bulk and promote the esterification reaction of FFA to produce biodiesel [73-74]. Ibrahim et al. [53] proposed a mechanism of esterification of palm fatty acid distillate (PFAD) catalyzed by a sulfonated solid catalyst from corncob (HTC-S). The solid acid catalyst provides protons those accepted by FFA. The $-\mathrm{SO}_{3} \mathrm{H}$ proton donor groups are generated by three oxygen atoms that pull the electrons cloud from sulfur and hydrogen. Afterward, the alcohol molecule attacks the protonated carbonyl group to form an intermediate that will release a water molecule to produce a protonated ester. In the last step, the proton is transferred back to the acid-solid catalyst and yields an ester or biodiesel (figure 4).

A variety of studies have been conducted to investigate the performance of corncob-derived solid acid catalysts as a potential heterogeneous catalyst for biodiesel production. The reaction time, temperature, catalyst loading, and alcohol to reactant molar ratio were evaluated to justify the catalytic activity of corncob-derived heterogeneous acid catalyst. The response of catalytic activity was expressed in FFA conversion or biodiesel yield.

The esterification of waste vegetable oil or fatty acid such as oleic acid in the presence of alcohol using corncob derived heterogeneous acid catalyst is a liquid-liquid-solid system. It 
requires the longer reaction time than homogeneous system to provide sufficient mass transfer between the liquid and the solid phase. Arancon et al. [50] reported that $98 \%$ of FAME yield was obtained after $6 \mathrm{~h}$ reaction using corncob derived heterogeneous acid as catalyst in the esterification of waste oil. In 2014, Ma et al. [39] also reported that for the same type of catalyst, the esterification of oleic acid reached $89.2 \%$ of product yield after $2 \mathrm{~h}$. Another study from Ibrahim et al. [53] revealed that the maximum FFA conversion (92\%) was obtained after $2 \mathrm{~h}$. They performed the esterification of palm fatty acid distillate in the presence of methanol catalyzed by corncob derived heterogeneous acid catalyst. According to this study, FFA conversion remained steady at $92 \%$ without any significant increase when the reaction time was increased into $4 \mathrm{~h}$. Farabi et al. [75] stated that since the esterification is reversible reaction, further prolonged reaction time might shift the reaction toward the reactant.

Thermodynamically, esterification reaction is an endothermic reaction. According to Tang et al [60] the activation energy of the esterification reaction between palm fatty acid and methanol, which was catalyzed by corncobderived heterogeneous acid was found to be $+23.36 \mathrm{~kJ}^{\mathrm{mol}}{ }^{-1}$. Increasing the temperature could drive the equilibrium toward the product [76]. Moreover, an increase in reaction temperature could reduce the mass transfer limitation between vegetable oil, alcohol, and solid catalyst. High temperature could decrease the viscosity of vegetable oil, and increase the miscibility between methanol and oil; thus, the FFA conversion will increase [53]. However, further increase in reaction temperature could not give a significant enhancement on FFA conversion due to the alcohol that tends to evaporate [77]. Ibrahim et al. [53] found that increasing the reaction temperature from $65^{\circ} \mathrm{C}$ to $70^{\circ} \mathrm{C}$ increased FFA conversion from $88 \%$ to $92 \%$. The FFA started to reduce FFA conversion when the reaction temperature increased from $70^{\circ} \mathrm{C}$ to $80^{\circ} \mathrm{C}$. The optimum reaction temperature of esterification between palm fatty acid distillate and methanol catalyzed by corncobderived heterogeneous acid was $70^{\circ} \mathrm{C}$. Another study by Hussain and Kumar [59] exhibited the optimum reaction temperature of esterification between Karanja oil and methanol using the same type of catalyst at $65^{\circ} \mathrm{C}$ with $90 \%$ conversion of FFA.

The corncob-derived heterogeneous acid catalyst provides acid active sites to facilitate the esterification reaction which can increase the FFA conversion rate. A large number of acidic sites could increase the availability of $\mathrm{H}^{+}$during esterification reaction [78]. However, excess catalyst in reaction system can lead to a mixing problem [76], the catalyst particles tend to self-agglomeration [78], and inhibit the mass transfer between catalyst, alcohol and feedstock [71]. According to Hussain and Kumar [59] the excess catalyst amount in reaction system causes the catalyst particles only float around the reactant and it could not increase the reaction rate. Hence, the optimum catalyst loading according to Ma et al. [39] and Hussain and Kumar [59] was 10\%. It is different from what Ibrahim et al.[53] found in which the optimum amount was $3 \%$, and $5 \%$ based on study performed by Tang et al. [60].

Stoichiometrically, the esterification reaction requires one mole of alcohol for one mol of vegetable oil. It is due to the esterification reaction that is a reversible reaction. The excess mol of alcohol is required to drive the reaction towards the product. For esterification reaction, which is catalyzed by corncob-derived heterogeneous acid, the optimum alcohol-tooil molar ratio is different dependent upon the feedstock and the amount of catalyst. Ma et al. [39] used the molar ratio of methanol-to-oleic acid, 10:1 and reached the best conversion of FFA at $89.2 \%$. Hussain and Kumar [59] found the highest conversion of FFA, 90\% with 20:1 of methanol-to-Karanja oil molar ratio. Ibrahim et al. [53] revealed that the optimum molar ratio of methanol-to-palm fatty acid distillate was 15:1 and reached $92 \%$ of FFA conversion. Other study by Tang et al. [60] found that 30:1 was the optimum molar ratio of methanol-to-palm fatty acid distillate. However, excess alcohol could dilute the reaction system and reduce the contact between catalyst and oil, and further it could hinder the protonation of oil and reaction rate becomes slow. Ibrahim et al [53] studied the effect of methanol-to-palm fatty acid distillate molar ratio on esterification reaction catalyzed by $3 \%$ corncob-derived heterogeneous acid at $70^{\circ} \mathrm{C}$ for $2 \mathrm{~h}$. they found that 15:1 was the optimum molar ratio of methanol-tofeedstock. Further increase in molar ratio of methanol-to-palm fatty acid to 20:1 and 25:1 decreased the FFA conversion. It is proven that large excess of alcohol in reaction system leads the low reaction rate.

Reusability is a very important property of corncobderived heterogeneous acid catalyst. The reusability test is performed for several cycles' reaction under an optimized condition. Previous studies exhibited that the performance of corncob-derived heterogeneous acid catalyst decreased after several cycles. Arancon et al [50] revealed that after 2 cycles reuse of catalyst, the FAME conversion only reached $17 \%$. Ma et al. [39] reported that it remained at $60 \%$ of FFA conversion after 8 cycles to reuse the catalyst in reaction. Ibrahim et al. [53] reported that after 5 cycles the FFA conversion remained 60\%, and Tang et al. [60] also reported after 5 cycles the FAME yield remained $50 \%$. The significant decrease in FFA conversion or FAME yield after several cycles to reuse corncob-derived heterogeneous acid as catalyst might be due to the leaching of the active sites [75], the blockage of the active sites by unreacted reactant and product [76], and the deactivation of active sites by water as byproduct of esterification reaction. The later one is difficult to avoid since the water generates during the esterification. The $\mathrm{OH}$ groups, which are also attached on surface of catalyst allow water adsorption. According to Hussan and Kumar [59] there is a competition between oil as reactant and water to adsorb on catalyst surface to lead to the deactivation of catalyst. Therefore, corncob-derived heterogeneous acid catalyst with high water resistant is desirable.

\section{Perspectives, Challenges, and Future Prospect}

According to the physical/chemical characterization and performance, the corncob-derived acid catalyst has high potential as a green-active catalyst for FFA esterification in biodiesel production, The utilization of corncob-derived heterogeneous acid catalysts could reach up to $90-98 \%$ of FFA conversion and $85 \%$ of biodiesel yield. Table 1 summarizes biodiesel production that utilizes corncob as solid 
acid catalysts. The challenges of corncob-derived solid acid catalyst utilization in the esterification reaction of vegetable oil are similar with the solid acid catalysts derived from other biomass waste. The low reaction rate, deactivation of catalyst by water as esterification by-product, formation of side reaction and the difficulty of maintaining the stability of performance in repetitive use are some general challenges of corncob-derived solid acid catalyst utilization as listed in table 2.

Some studies are required to further modify the surface of corncob-derived solid acid catalyst which is allowable to control the accessibility of vegetable oil molecules into the acid active site and to maintain the stability of the acid active sites. As the catalyst is easy to be deactivated by water, there could be interesting if the surface of catalyst modifies and engineers for having water resistant properties using novel method. However, the proposed ideas and methods to enhance the catalytic activity of corncob-derived solid acid catalyst should be in harmony with the final goal, providing the simple, safe, environmentally friendly and cost-effectiveness method to synthesize biodiesel.

Table 2. The drawbacks and possible causes for the utilization of corncob-derived heterogeneous acid catalyst.

\begin{tabular}{lcc}
\hline \multicolumn{1}{c}{ Drawback } & Possible causes & Ref. \\
\hline $\begin{array}{l}\text { Longer reaction time } \\
\text { Higher reaction } \\
\text { temperature }\end{array}$ & $\begin{array}{c}\text { Miscibility between high-viscosity feedstock and methanol; catalytic acid site } \\
\text { covered by water (by-product of esterification) absorbed onto surface. }\end{array}$ & {$[50-53]$} \\
$\begin{array}{l}\text { Sel-agglomeration of } \\
\text { catalyst particles }\end{array}$ & excess catalyst loading & {$[59-60]$} \\
$\begin{array}{l}\text { The hindrance of } \\
\text { feedstock protonation }\end{array}$ & Larger methanol amount could dilute the system & {$[39-53-59-60]$} \\
$\begin{array}{l}\text { Formation side reaction } \\
\text { Deactivation of active } \\
\text { acid site }\end{array}$ & The -OH groups on surface of catalyst attract water, and water hydrolyzes the active & {$[53]$} \\
\hline
\end{tabular}

\section{Conclusion}

Heterogeneous acid catalysts have an enormous potential to replace conventional catalysts in biodiesel production with good efficiency. They are suitable for low quality feedstock containing high FFA and able to reduce the production cost for biodiesel production. Recently, biomass waste derived heterogeneous acid catalyst is the best candidate for the cost reduction purpose and safe for the environment. Corncob is one of biomass wastes that has been utilized as raw material for solid acid catalyst preparation. A sulfonated corncob derived heterogeneous catalyst has been successfully synthesized by hydrothermal technique both for carbonization and sulfonation. The catalyst has been applied in the esterification reaction of the low-quality vegetable oil and exhibited a high yield of biodiesel. However, further development of corncob derived heterogeneous acid catalysts is still required for a better performance in biodiesel production.

\section{Acknowledgements}

This work is granted by PDWM LPPM-ULM under contract No.009.28/UN8.2/PL/2021. The authors would like to express sincere gratitude for the support of LPPM-ULM and Engineering faculty of ULM.

\section{References}

1. A. L. Ahmad, N. H. M. Yasin, C. J. C. Derek, \& J. K. Lim, Microalgae as a sustainable energy source for biodiesel production: A review. Renew Sustain Energy Rev, 15 (2011) 584-593.

2. M. E. Borges \& L. Díaz, Recent developments on heterogeneous catalysts for biodiesel production by oil esterification and transesterification reactions: A review. Renew Sustain Energy Rev, 16 (2012) 2839-2849.

3. B. Singh, A. Guldhe, I. Rawat, \& F. Bux, Towards a sustainable approach for development of biodiesel from plant and microalgae. Renew Sustain Energy Rev, 29 (2014) 216-245.

4. Y. M. Sani, W. M. A. W. Daud, \& A. R. Abdul Aziz, Activity of solid acid catalysts for biodiesel production: A critical review. Appl Catal A: Gen, 470 (2014) 140-161.

5. N. Sarkar, S. K. Ghosh, S. Bannerjee, \& K. Aikat, Bioethanol production from agricultural wastes: An overview. Renew Energy, 37 (2012) 19-27.

6. M. F. Rabiah Nizah, Y. H. Taufiq-Yap, U. Rashid, S. H. Teo, Z. A. Shajaratun Nur, \& A. Islam, Production of biodiesel from non-edible Jatropha curcas oil via transesterification using Bi2O3-La2O3 catalyst. Energy Convers Manag., 88 (2014) 1257-1262.

7. P. Mardina, C. Irawan, M. D. Putra, S. B. Priscilla, M. Misnawati, \& I. F. Nata, Bioethanol Production from Cassava Peel Treated with Sulfonated Carbon Catalyzed Hydrolysis. J. kim. sains apl., 24 (2021) 1-8.

8. B. L. A. P. Devi, T. V. K. Reddy, K. V. Lakshmi, \& R. B. N. Prasad, A green recyclable SO3H-carbon catalyst derived from glycerol for the production of biodiesel from FFA-containing karanja ( Pongamia glabra ) oil in a single step. Bioresour Technol., 153 (2014) 370-373.

9. Z. Yaakob, M. Mohammad, M. Alherbawi, Z. Alam, \& K. Sopian, Overview of the production of biodiesel from Waste cooking oil. Renew Sustain Energy Rev, 18 (2013) 184-193.

10. Z. A. Shajaratun Nur, Y. H. Taufiq-Yap, M. F. Rabiah Nizah, S. H. Teo, O. N. Syazwani, \& A. Islam, Production of biodiesel from palm oil using modified Malaysian natural dolomites. Energy Convers Manag., 78 (2014) 738-744.

11. M. Takase, T. Zhao, M. Zhang, Y. Chen, H. Liu, L. Yang, \& X. Wu, An expatiate review of neem, jatropha, rubber and karanja as multipurpose non-edible biodiesel resources and comparison of their fuel, engine and emission properties. Renew Sustain Energy Rev, 43 (2015) 495-520.

12. A. M. Dehkhoda, A. H. West, \& N. Ellis, Biochar based solid acid catalyst for biodiesel production. Appl Catal A: Gen, 382 (2010) 197204. 
13. D. Y. C. Leung, X. Wu, \& M. K. H. Leung, A review on biodiesel production using catalyzed transesterification. Appl Energy, 87 (2010) 1083-1095.

14. S. H. Y. S. Abdullah, N. H. M. Hanapi, A. Azid, R. Umar, H. Juahir, H. Khatoon, \& A. Endut, A review of biomass-derived heterogeneous catalyst for a sustainable biodiesel production. Renew Sustain Energy Rev, 70 (2016) 1040-1051.

15. Z. Tang, S. Lim, Y. Pang, H. Ong, \& K. Lee, Synthesis of biomass as heterogeneous catalyst for application in biodiesel production: State of the art and fundamental review. Renew Sustain Energy Rev, 92 (2018) 235-253.

16. I. Reyero, G. Arzamendi, S. Zabala, \& L. M. Gandía, Kinetics of the $\mathrm{NaOH}$-catalyzed transesterification of sunflower oil with ethanol to produce biodiesel. Fuel Process Technol., 129 (2015) 147-155.

17. K. Neumann, K. Werth, A. Martín, \& A. Górak, Biodiesel production from waste cooking oils through esterification: Catalyst screening, chemical equilibrium and reaction kinetics. Chem Eng Res Des, 107 (2016) 52-62.

18. A. Islam, Y. H. Taufiq-Yap, E. S. Chan, M. Moniruzzaman, S. Islam, \& M. N. Nabi, Advances in solid-catalytic and non-catalytic technologies for biodiesel production. Energy Convers Manag., 88 (2014) 1200-1218.

19. S. Semwal, A. K. Arora, R. P. Badoni, \& D. K. Tuli, Biodiesel production using heterogeneous catalysts. Bioresour Technol., 102 (2011) 21512161.

20. L. J. Konwar, J. Boro, \& D. Deka, Review on latest developments in biodiesel production using carbon-based catalysts. Renew Sustain Energy Rev, 29 (2014) 546-564.

21. N. Mansir, Y. H. Taufiq-yap, U. Rashid, \& I. M. Lokman, Investigation of heterogeneous solid acid catalyst performance on low grade feedstocks for biodiesel production : A review. Energy Convers Manag., (2016).

22. Y. D. Long, Z. Fang, T. C. Su, \& Q. Yang, Co-production of biodiesel and hydrogen from rapeseed and Jatropha oils with sodium silicate and Ni catalysts. Appl Energy, 113 (2014) 1819-1825.

23. Y. M. Sani, W. M. A. W. Daud, \& A. R. Abdul Aziz, Solid acidcatalyzed biodiesel production from microalgal oil - The dual advantage. J Environ Chem Eng, 1 (2013) 113-121.

24. F. Ezebor, M. Khairuddean, A. Z. Abdullah, \& P. L. Boey, Esterification of oily-FFA and transesterification of high FFA waste oils using novel palm trunk and bagasse-derived catalysts. Energy Convers Manag., 88 (2014) 1143-1150

25. M. Tariq, S. Ali, \& N. Khalid, Activity of homogeneous and heterogeneous catalysts, spectroscopic and chromatographic characterization of biodiesel: A review. Renew Sustain Energy Rev, 16 (2012) 6303-6316.

26. A. Takagaki, M. Toda, M. Okamura, J. N. Kondo, S. Hayashi, K. Domen, \& M. Hara, Esterification of higher fatty acids by a novel strong solid acid. Catal Today, 116 (2006) 157-161.

27. A. Galadima \& O. Muraza, Biodiesel production from algae by using heterogeneous catalysts: A critical review. Energy, 78 (2014) 72-83.

28. S. H. Teo, M. Goto, \& Y. H. Taufiq-Yap, Biodiesel production from Jatropha curcas L. oil with Ca and La mixed oxide catalyst in near supercritical methanol conditions. J Supercritical Fluids, 104 (2015) 243 250.

29. A. P. S. Chouhan \& A. K. Sarma, Modern heterogeneous catalysts for biodiesel production: A comprehensive review. Renew Sustain Energy Rev, 15 (2011) 4378-4399.

30. E. Taer, L. Pratiwi, Apriwandi, W. S. Mustika, R. Taslim, \& Agustino, Three-dimensional pore structure of activated carbon monolithic derived from hierarchically bamboo stem for supercapacitor application. CST, 5 (2020) 22-30.
31. A. B. D. Nandiyanto, G. C. S. Girsang, R. Maryanti, R. Ragadhita, S. Anggraeni, F. M. Fauzi, P. Sakinah, et al., Isotherm adsorption characteristics of carbon microparticles prepared from pineapple peel waste. CST, 5 (2020) 31-39.

32. A. Chafidz, A. R. Afandi, B. M. Rosa, J. Suhartono, P. Hidayat, \& H. Junaedi, Production of silver nanoparticles via green method using banana raja peel extract as a reducing agent. CST, 5 (2020) 112-118.

33. I. F. Nata, C. Irawan, P. Mardina, \& C. Lee, Carbon-based strong solid acid for cornstarch hydrolysis. J Solid State Chem, 230 (2015) 163-168.

34. D. R. Lathiya, D. V Bhatt, \& K. C. Maheria, Synthesis of sulfonated carbon catalyst from waste orange peel for cost effective biodiesel production. Bioresour Technol Rep, 2 (2018) 69-76.

35. F. Ezebor, M. Khairuddean, A. Z. Abdullah, \& P. L. Boey, Oil palm trunk and sugarcane bagasse derived heterogeneous acid catalysts for production of fatty acid methyl esters. Energy, 70 (2014) 493-503.

36. X. Liu, M. Huang, H. Ma, Z. Zhang, J. Gao, Y. Zhu, X. Han, \& X. Guo, Preparation of a Carbon-Based Solid Acid Catalyst by Sulfonating Activated Carbon in a Chemical Reduction Process. Molecules, 15 (2010) 7188-7196.

37. J. R. Kastner, J. Miller, D. P. Geller, J. Locklin, L. H. Keith, \& T. Johnson, Catalytic esterification of fatty acids using solid acid catalysts generated from biochar and activated carbon. Catal Today, 190 (2012) 122-132.

38. F. E. Babadi, S. Hosseini, S. M. Soltani, M. K. Aroua, A. Shamiri, \& M. Samadi, Sulfonated Beet Pulp as Solid Catalyst in One-Step Esterification of Industrial Palm Fatty Acid Distillate. J Am Oil Chem Soc, 93 (2016) 319-327.

39. H. Ma, J. Li, W. Liu, B. Cheng, X. Cao, J. Mao, \& S. Zhu, Hydrothermal Preparation and Characterization of Novel Corncob-Derived Solid Acid Catalysts. J Agric Food Chem, 62 (2014) 5345-5353.

40. S. Pandian, S. S. Arumugamurthi, P. Sivanandi, M. Santra, \& V. K. Booramurthy, 4-Application of heterogeneous acid catalyst derived from biomass for biodiesel process intensification: a comprehensive review. Refining Biomass Residues for Sustainable Energy and Bioproducts. Academic Press, 2020.

41. Z. Liu, A. Quek, S. K. Hoekman, \& R. Balasubramanian, Production of solid biochar fuel from waste biomass by hydrothermal carbonization. Fuel, 103 (2013) 943-949.

42. S. De, M. Balu, J. C. Van Der Waal, \& R. Luque, Biomass-Derived Porous Carbon Materials: Synthesis and Catalytic Applications. ChemCatCHem, 7 (2015) 1608-1629.

43. M. Li, Y. Zheng, Y. Chen, \& X. Zhu, Biodiesel production from waste cooking oil using a heterogeneous catalyst from pyrolyzed rice husk. Bioresour Technol., 154 (2014) 345-348.

44. F. A. Dawodu, O. Ayodele, J. Xin, S. Zhang, \& D. Yan, Effective conversion of non-edible oil with high free fatty acid into biodiesel by sulphonated carbon catalyst. Appl Energy, 114 (2014) 819-826.

45. Ministry of Agriculture, Petunjuk Pelaksanaan Kegiatan Budidaya Jagung Tahun 2017. Jakarta, 2018.

46. J. A. Kabalmay, E. Suryanto, \& M. R. J. Runtuwene, Nano Kitosan Ekstrak Tongkol Jagung Manado Kuning ( Zea Mays L .) Dan Aktivitas Antioksidannya. Chem Prog, 12 (2019) 13-18.

47. W. Qu, Y. Xu, A. Lu, X. Zhang, \& W. Li, Converting biowaste corncob residue into high value added porous carbon for supercapacitor electrodes. Bioresour Technol., 189 (2015) 285-291.

48. S. Prasad, A. Singh, \& H. C. Joshi, Ethanol as an alternative fuel from agricultural, industrial and urban residues. Resour Conserv Recycl, 50 (2007) 1-39.

49. M. Takada, R. Niu, E. Minami, \& S. Saka, Characterization of three tissue fractions in corn (Zea mays) cob. Biomass Bioenergy, 115 (2018) 
130-135.

50. R. A. Arancon, H. R. Barros Jr, A. M. Balu, C. Vargas, \& R. Luque, Valorisation of corncob residues to functionalised porous carbonaceous materials for the simultaneous esterification / transesterification of waste. Green Chem., 13 (2011) 3162-3167.

51. P. D. Rocha, L. S. Oliveira, \& A. S. Franca, Sulfonated activated carbon from corn cobs as heterogeneous catalysts for biodiesel production using microwave-assisted transesterification. Renew Energy, 143 (2019) 1710 1716.

52. W. Mateo, H. Lei, E. Villota, M. Qian, Y. Zhao, E. Huo, Q. Zhang, X. Lin, C. Wang, \& Z. Huang, Synthesis and characterization of sulfonated activated carbon as a catalyst for bio-jet fuel production from biomass and waste plastics. Bioresour Technol., 297 (2020) 122411.

53. S. F. Ibrahim, N. Asikin-mijan, M. L. Ibrahim, G. Abdulkareem-alsultan, S. M. Izhma, \& Y. H. Taufiq-yap, Sulfonated functionalization of carbon derived corncob residue via hydrothermal synthesis route for esterification of palm fatty acid distillate. Energy Convers Manag., 210 (2020) 112698.

54. A. Shariff, N. S. M. Aziz, N. I. Ismail, \& N. Abdullah, Corn cob as a potential feedstock for slow pyrolysis of biomass. J Phys Sci, 27 (2016) 123-137.

55. M. Garcia-Perez, A. Chaala, \& C. Roy, Vacuum pyrolysis of sugarcane bagasse. J Anal Appl Pyrolysis, 65 (2002) 111-136.

56. R. N. Singh, D. K. Vyas, N. S. L. Srivastava, \& M. Narra, SPRERI experience on holistic approach to utilize all parts of Jatropha curcas fruit for energy. Renew Energy, 33 (2008) 1868-1873.

57. I. Brodin, Chemical Properties and Thermal Behaviour of Kraft Lignins. Stockholm. KTH Royal Institute of Technology, 2009.

58. C. M. Mendaros, A. W. Go, W. J. T. Nietes, B. E. J. O. Gollem, \& L. K. Cabatingan, Direct sulfonation of cacao shell to synthesize a solid acid catalyst for the esteri fi cation of oleic acid with methanol. Renew Energy, 152 (2020) 320-330.

59. Z. Hussain \& R. Kumar, Synthesis And Characterization Of Novel Corncob-Based Solid Acid Catalyst For Biodiesel Production. Ind Eng Chem Res, 57 (2018) 11645-11657.

60. Z. Tang, S. Lim, Y. Pang, S. Shuit, \& H. Ong, Utilization of biomass wastes based activated carbon supported heterogeneous acid catalyst for biodiesel production. Renew Energy, 158 (2020) 91-102.

61. V. Hernández-montoya \& A. Bonilla-petriciolet, Lignocellulosic Precursors Used in the Synthesis of Activated Carbon:Characterization Techniques and Applications in the Wastewater Treatment. Croatia. InTech,2012).

62. N. Mohamad Nor, L. L. Chung, L. K. Teong, \& A. R. Mohamed, Synthesis of activated carbon from lignocellulosic biomass and its applications in air pollution control - a review. J Environ Chem Eng, 1 (2013) 658-666.

63. M. Hara, T. Yoshida, A. Takagaki, T. Takata, J. N. Kondo, S. Hayashi, \& K. Domen, A carbon material as a strong protonic acid. Angew Chem Int Ed, 43 (2004) 2955-2958.

64. S. Rovani, A. G. Rodrigues, L. F. Medeiros, R. Cataluña, É. C. Lima, \& A. N. Fernandes, Synthesis and characterisation of activated carbon from agroindustrial waste - Preliminary study of 17 b -estradiol removal from aqueous solution. J Environ Chem Eng, 4 (2016) 2128-2137.

65. I. F. Nata, M. D. Putra, D. Nurandini, \& C. Irawan, Facile Strategy for Surface Functionalization of Corn Cob to Biocarbon and Its Catalytic Performance on Banana Peel Starch Hydrolysis. IJASEIT, 7 (2017) 1302-1308.

66. M. Titirici \& M. Antonietti, Chemistry and materials options of sustainable carbon materials made by hydrothermal carbonization. Chem Soc Rev, 39 (2010) 103-116.

67. M. T. Reza, M. H. Uddin, J. G. Lynam, S. K. Hoekman, \& C. J. Coronella, Hydrothermal carbonization of loblolly pine: reaction chemistry and water balance. Biomass Convers Biorefin, 4 (2014) 311321.

68. M. Harmas, T. Thomberg, H. Kurig, T. Romann, A. Janes, \& E. Lust, Microporous e mesoporous carbons for energy storage synthesized by activation of carbonaceous material by zinc chloride, potassium hydroxide or mixture of them. J Power Sources, 326 (2016) 624-634.

69. S. Akinfalabi, U. Rashid, R. Yunus, \& Y. H. Taufiq-yap, Synthesis of biodiesel from palm fatty acid distillate using sulfonated palm seed cake catalyst. Renew Energy, 111 (2017) 611-619.

70. A. M. Dehkhoda \& N. Ellis, Biochar-based catalyst for simultaneous reactions of esterification and transesterification. Catal Today, 207 (2013) 86-92.

71. I. M. Lokman, U. Rashid, Y. Hin, \& R. Yunus, Methyl ester production from palm fatty acid distillate using sulfonated glucose-derived acid catalyst. Renew Energy, 81 (2015) 347-354.

72. K. Ngaosuwan, J. G. Goodwin Jr., \& P. Prasertdham, A green sulfonated carbon-based catalyst derived from coffee residue for esteri fi cation. Renew Energy, 86 (2016) 262-269.

73. M. Tao, H. Guan, X. Wang, Y. Liu, \& R. Louh, Fabrication of sulfonated carbon catalyst from biomass waste and its use for glycerol esteri fi cation. Fuel Process Technol., 138 (2015) 355-360.

74. H. H. Mardhiah, H. Chyuan, H. H. Masjuki, S. Lim, \& Y. Ling, Investigation of carbon-based solid acid catalyst from Jatropha curcas biomass in biodiesel production. Energy Convers Manag., 144 (2017) $10-17$.

75. M. S. A. Farabi, M. L. Ibrahim, U. Rashid, \& Y. Hin, Esterification of palm fatty acid distillate using sulfonated carbon-based catalyst derived from palm kernel shell and bamboo. Energy Convers Manag., 181 (2019) $562-570$

76. Y. Zhou, S. Niu, \& J. Li, Activity of the carbon-based heterogeneous acid catalyst derived from bamboo in esterification of oleic acid with ethanol. Energy Convers Manag., 114 (2016) 188-196.

77. A. P. da L. Correa, R. R. C. Bastos, G. N. da R. Filho, J. R. Zamian, \& L. R. V. da Conceicao, Preparation of sulfonated carbon-based catalysts from murumuru kernel shell and their performance in the esterification reaction. RSC Adv., 10 (2020) 20245-20256.

78. I. Thushari \& S. Babel, Sustainable utilization of waste palm oil and sulfonated carbon catalyst derived from coconut meal residue for biodiesel production. Bioresour Technol., 248 (2017) 199-203. 